\title{
New Wine from Old Grapes: Innovation in the Eco-Friendly B2C Space
}

Article in Journal of International Consumer Marketing · February 2015

DOI: $10.1080 / 08961530.2014 .985539$

\section{CITATIONS}

0

3 authors:

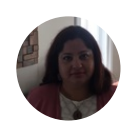

\section{Malika Chaudhuri}

University of Dayton

4 PUBLICATIONS 2 CITATIONS

SEE PROFILE

Praneet Randhawa

University of Baltimore

6 PUBLICATIONS 21 CITATIONS

SEE PROFILE

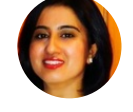

READS

30

Some of the authors of this publication are also working on these related projects: 
This article was downloaded by: [Malika Chaudhuri]

On: 17 March 2015, At: 06:26

Publisher: Routledge

Informa Ltd Registered in England and Wales Registered Number: 1072954 Registered office: Mortimer House, 37-41 Mortimer Street, London W1T 3J H, UK

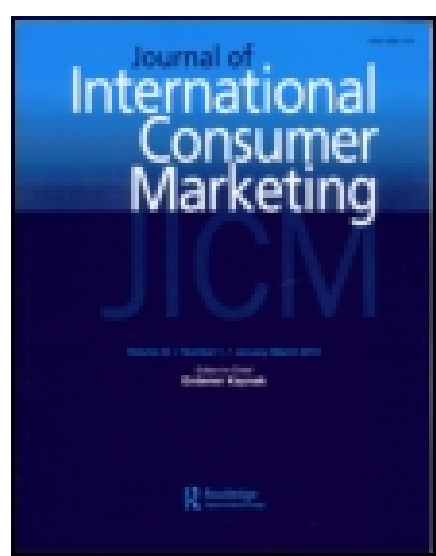

\section{J ournal of International Consumer Marketing}

Publication details, including instructions for authors and subscription information: http:// www.tandfonline.com/loi/ wicm20

\section{New Wine from Old Grapes: Innovation in the Eco- Friendly B2C Space}

Malika Chaudhuri, Roger J . Calantone \& Praneet Randhawa

Published online: 25 Feb 2015.

\section{CrossMark}

\section{Click for updates}

To cite this article: Malika Chaudhuri, Roger J . Calantone \& Praneet Randhawa (2015) New Wine from Old Grapes: Innovation in the Eco-Friendly B2C Space, J ournal of International Consumer Marketing, 27:2, 99-122, DOI: $10.1080 / 08961530.2014 .985539$

To link to this article: http:// dx.doi.org/ 10.1080/ 08961530.2014.985539

\section{PLEASE SCROLL DOWN FOR ARTICLE}

Taylor \& Francis makes every effort to ensure the accuracy of all the information (the "Content") contained in the publications on our platform. However, Taylor \& Francis, our agents, and our licensors make no representations or warranties whatsoever as to the accuracy, completeness, or suitability for any purpose of the Content. Any opinions and views expressed in this publication are the opinions and views of the authors, and are not the views of or endorsed by Taylor \& Francis. The accuracy of the Content should not be relied upon and should be independently verified with primary sources of information. Taylor and Francis shall not be liable for any losses, actions, claims, proceedings, demands, costs, expenses, damages, and other liabilities whatsoever or howsoever caused arising directly or indirectly in connection with, in relation to or arising out of the use of the Content.

This article may be used for research, teaching, and private study purposes. Any substantial or systematic reproduction, redistribution, reselling, loan, sub-licensing, systematic supply, or distribution in any form to anyone is expressly forbidden. Terms \& Conditions of access and use can be found at http:// www.tandfonline.com/page/terms-and-conditions 


\title{
New Wine from Old Grapes: Innovation in the Eco-Friendly B2C Space
}

\author{
Malika Chaudhuri \\ Roger J. Calantone \\ Praneet Randhawa
}

\begin{abstract}
Despite the upsurge in the need to develop eco-friendly products, few research studies have empirically examined consumers' preferences for eco-friendly products. We use a choice-based, conjoint analysis method to estimate willingness to pay for alternative transportation fuels in the United States. Unleaded gasoline and ethanol (derived from corn or cellulosic biomass) are the alternative fuels considered in this study. We use a latent class model and introduce sociodemographic variables, such as age of consumers and state of residency, to identify consumer preference heterogeneity. The findings of this study hold important implications for both firms and policy makers. Furthermore, less-polluting fuels is a global problem; conjoint studies are easy to project cross-culturally, as the design and findings can be reexamined and replicated in many locales worldwide.
\end{abstract}

KEYWORDS. Eco-innovations, willingness to pay, alternative fuels, latent class, conjoint analysis, preference heterogeneity

\section{INTRODUCTION}

The development and diffusion of environmentally friendly products and processes offer the best odds for reducing pollution without affecting product and service outputs (Lanjouw and Mody 1996). This is one of the apparent causes behind the necessity to develop products that are safe for the environment. Consequently, this trend has led to the rise of research on topics related to eco-innovations (e.g., Conway and Steward 1998; Foster and Green 2002; Pujari, Wright and Peattie 2003; Pujari, Peattie and Wright 2004). Eco-innovation is broadly defined as designing or redesigning products and/or processes to meet the challenges of sustainable development (Rennings 2000; Pujari 2006; Hellström 2007; Carrillo-Hermosilla, del Río and Konnola 2010).

There is increasing pressure on firms to build products that assist in saving the planet, but

Malika Chaudhuri is affiliated with the Department of Marketing in the Eli Broad College of Business at Michigan State University, East Lansing, Michigan, USA. Roger J. Calantone is affiliated with the Department of Marketing in the Eli Broad College of Business at Michigan State University, East Lansing, Michigan, USA. Praneet Randhawa is affiliated with the Department of Marketing and Entrepreneurship in the Merrick School of Business at the University of Baltimore, Baltimore, Maryland, USA.

Address correspondence to Malika Chaudhuri, Department of Marketing, Michigan State University, N462 North Business Complex, East Lansing, MI 48824, USA. E-mail: chaudhurim@bus.msu.edu 
despite of this pressure there is resentful acceptance from both consumers and firms because of the inherent tradeoffs that have to be made. Consumers have to pay a comparatively higher price, and firms have higher production costs and relatively reduced competitiveness (Porter and Van der Linde 1995). The intriguing question to address here is, why do firms adopt ecoinnovations? Extant literature suggests that firms with a majority market share often tend to lobby for implementation of administrative innovations that seem lucrative to the lobbying firms (Gerard and Lave 2005). These innovations involve adoption of administrative programs, techniques, or processes that are new to the innovating firm (Teece 1980). Hence, such innovations necessitate manufacturing firms to change their administrative processes and organizational structures, which may involve significant reallocation of resources and restructuring of tasks (Mahajan, Sharma, and Bettis 1988). Adoption of oxidation catalytic converters and three-way catalysts during the 1970s and 1980s and hybrid electric vehicles during the 2000s (Burke 2004) are examples of introduction of energy-efficient and low-emitting technology by U.S. auto manufacturers to achieve compliance with federal mandates and regulations.

Even though all the firms are subject to the same industry standards, some may enjoy advantage over the others, since production cost structure tends to vary across the firms. Additionally, administrative innovations often involve significant "set-up" costs and organizational disruption (Teece 1980). Compliance with such regulations tends to increase cost of production, with no significant increase in revenue, which may actually deplete firms' profit. However, the dominant firms, who predominantly lobby for implementation of such regulations, may have already adopted these structural changes and hence may not be exposed to such administrative shocks and financial costs. Thus, these federal policies often put the squeeze on small manufacturers and entrepreneurs, choke competition, and help large firms to improve upon their market share. Additionally, firms' product offerings that are in compliance with administrative innovations rather than being driven by technological innovations often lack consumer enthusiasm (Heiskanen et al. 2007). Consumer enthusiasm is critical for the successfully adoption of ecoinnovations because in the end it's consumers who decide the fate of a new product in the marketplace (Jansson 2011).

Despite the upsurge in the need to develop eco-friendly products, research in this field has primarily looked at corporate and business strategies for being environmentally friendly, and relatively fewer studies have empirically examined consumers' preference for eco-innovations (Ozaki 2011; Tully and Winer 2013). Current research on consumer attitudes toward sustainable products is filled with multiple findings and hence is still a heated debate. One set of researchers argues that consumers are willing to pay more for eco-innovations (Shrum, McCarty and Lowrey 1995; Ottman 1998; Rowlands, Scott, and Parker 2003), while another set of researchers argues that there is no evidence of consumer-driven environmentalism (Wong, Turner and Stoneman 1996; Peattie 2001; Peattie and Crane 2005). A probable cause behind such heated debate is the methodologies used to study consumer attitudes. Amendah and Park (2008) argue that consumer eco-innovation studies are fraught with methodological errors that make generalizability of the existing results difficult. This suggests that examining consumers' preferences for eco-innovations is still an open question that needs to be addressed using a rigorous method. Researchers still need to clearly find out what consumers are willing to pay for ecoinnovations (Tully and Winer 2013).

In our view, the first step toward unfolding this complex mechanism begins with the examination of consumer preferences for adopting flexible fuels, in order to fully comprehend the various factors leading to its successful adoption in the marketplace. Additionally, research shows that demand factors, such as ever-changing needs of the customer base as well as overall societal requirements, have been generally overlooked in the literature (Kesidou and Demirel 2012).

The literature suggests that the derived demand for an industrial product is the 
numerical integration of individual consumer demand for the product and is a reflection of its market share (Melnikov 2000). In the context of the current research, an understanding of derived demand for alternative transportation fuel entails a detailed analysis of consumer demand for the product, which in turn, requires an explicit understanding of consumer preference structure and factors that may influence such preference patterns (Huang 1996; Grunert 2005). The literature defines preferences over the product characteristic space and assumes that consumers reveal inclination for the product that yields the highest utility value (Melnikov 2000). In particular, consumer preference structure is influenced by sociodemographic factors as well as product characteristics (Boxall and Adamowicz 2002). In this study, we use choice-based, conjoint analysis to capture consumers' heterogeneous preference structure and estimate consumers' willingness to pay (WTP) for alternative transportation fuels in the United States. Table 1 illustrates a typical choice scenario where the respondents are required to choose one of the alternatives contingent on the product characteristics they have been exposed to.

This study makes a unique contribution to the literature by empirically examining consumer preferences for eco-friendly products, including their price sensitivity. Our results show that consumers' price sensitivity is a crucial factor impacting the adoption of ecoinnovations. Additionally, the results show that consumer preferences for flexible fuels fall under four types of categories-corn-based ethanol rejecter, confused but concerned, cellulosic ethanol accepter, and ethanol enthusiast-based on their attitude toward flexible fuel consumption. The analysis of trade-offs driven by consumers' preference heterogeneity provides researchers and managers muchneeded input that often influences critical marketing decisions related to new product design, pricing, and positioning.

The remainder of the article is organized as follows. The next section provides us with the theoretical background with an overview on the existing research on alternative fuels and the methodology. Next, in the sampling and methodology section, we describe the latent class model (LCM) and present a description of the research design. Then we provide a discussion of the model of fuel choice. Last, we provide the empirical specifications and results and conclude the article with research and managerial implications.

\section{THEORETICAL BACKGROUND}

Eco-innovations, or new product development in the form of sustainable development, have taken different forms. The current

FIGURE 1. An Example of Choice Scenario from the Choice Experiment

\begin{tabular}{|l|c|c|c|c|}
\hline & Gasoline & E-10 & E-85 & Not Purchase \\
\hline Fuel Cost & $\$ 731.25$ & $\$ 989.34$ & $\$ 731.25$ & \\
\hline $\begin{array}{l}\text { Fuel } \\
\text { Availability (\% } \\
\text { of existing } \\
\text { stations) }\end{array}$ & $100 \%$ & $50 \%$ & $25 \%$ & \\
\cline { 1 - 4 } $\begin{array}{l}\text { Emission } \\
\text { (pounds/gallon) }\end{array}$ & 19.4 & 9.7 & 14.55 & $\begin{array}{l}\text { I choose not } \\
\text { to purchase } \\
\text { either of these } \\
\text { products. }\end{array}$ \\
\cline { 1 - 4 } Bio-Feedstock & $\begin{array}{c}\text { Not } \\
\text { Applicable }\end{array}$ & $\begin{array}{c}\text { Cellulose: } \\
\text { Switch Grass }\end{array}$ & $\begin{array}{c}\text { Cellulose: } \\
\text { Corn Stalks }\end{array}$ & \\
\cline { 1 - 4 } $\begin{array}{l}\text { Cost of buying } \\
\text { and } \\
\text { maintaining the } \\
\text { vehicle }\end{array}$ & $\$ 21,500$ & $\$ 19,350$ & $\$ 19,350$ & \\
\hline I Choose & $\square$ & $\square$ & $\square$ & $\square$ \\
\hline
\end{tabular}


TABLE 1. An Example of Choice Scenario from the Choice Experiment

\begin{tabular}{|c|c|c|c|c|}
\hline & Gasoline & $E-10$ & E-85 & Not purchase \\
\hline Fuel cost & $\$ 731.25$ & $\$ 989.34$ & $\$ 731.25$ & \\
\hline $\begin{array}{l}\text { Fuel availability (\% of } \\
\text { existing stations) }\end{array}$ & 100 percent & 50 percent & 25 percent & $\begin{array}{l}\text { I choose not to purchase } \\
\text { either of these products. }\end{array}$ \\
\hline Emission (pounds/gallon) & 19.4 & 9.7 & 14.55 & \\
\hline Bio-feedstock & Not Applicable & $\begin{array}{l}\text { Cellulose: } \\
\quad \text { Switch Grass }\end{array}$ & Cellulose: Corn Stalks & \\
\hline $\begin{array}{l}\text { Cost of buying and } \\
\text { maintaining the vehicle }\end{array}$ & $\$ 21,500$ & $\$ 19,350$ & $\$ 19,350$ & \\
\hline I choose & $\square$ & $\square$ & $\square$ & $\square$ \\
\hline
\end{tabular}

research argues that the goals of social good and business success are being driven together (Porter and Van der Linde, 1995; Menon and Menon 1997; Pujari 2006). Firms nowadays are required to build products that not only cater to the needs of the customers but also contribute to the sustainable growth of the planet. Ecoinnovations are either driven by new policies or by market needs (Pujari et al. 2003). Both push and pull strategies can be important for driving innovation (Zhang, Gensler, and García 2011). According to Zhang and colleagues (2011), pushing eco-innovations in the market without consumer demand is a waste of effort. Moreover, Pujari and colleagues (2004) argue that for eco-innovations to be successful, they need to be effective in their marketplace performance. This implies that understanding consumer demand is an incredibly important aspect because eco-innovations involve higher production costs when compared to development of traditional products. Products that meet the needs of the customers are adopted swiftly. Yet, products built on the idea of conserving the environment are increasingly being viewed with serious cynicism by consumers (GrayLee, Scammon, and Mayer 1994). This suggests that there is a need for a thorough understanding of consumer preferences for successful adoption by the consumers.

Studies on consumer demand for alternative transportation fuels are few and limited in scope. Greene (1989) investigated consumer sensitivity of fuel choice to fuel prices and found that consumers are very sensitive of fuel choice because of fuel prices. Bhattacharjee, Petrolia, and Herndon (2008) measured U.S. consumer's WTP for E-10 fuel by using a contingent valuation technique. The authors found that respondents identified as "liberals" have significantly higher WTP for flexible fuels, and this WTP is significantly higher for males and for those consumers who are ethanol conscious. Interestingly, supporters of alternative fuels who are unsympathetic toward ethanol have significantly lower WTP for E-10. Most research to date has focused on understanding the potential demand for alternative flexible fuel vehicles (AFVs). According to the results of various studies conducted, different factors or combination of factors lead to consumers' adoption of AFVs in the automobile industry. According to Ewing and Sarigollu (2000), consumers value the environmentally friendly aspect of the AFVs, but their preference for buying them is greatly driven by the performance of the AFVs. Nevertheless, the authors find that government mandates and regulations have been effective in generating investment in manufacturing of AFVs, but it does not drive the demand for AFVs by the consumers. Similarly, the findings of the study by Ahn, Jeong, and Kim (2008) show that on average, gasoline-fueled cars will still be consumers' first choice. However, the authors argue that the introduction of alternative-fuel passenger cars in the market would lead to effectively lowering the demand for gasoline and diesel fuel, which would lead to the reduction in the emission of pollutants. Extant research has also examined conditions under which consumers will be motivated to buy AFVs. According to Potoglou and Kanaroglou's (2007), the potential demand for clean-fuel vehicles is driven by 
reduced monetary costs, lower emission rates, and tax relief, rather than the incentives of driving in the high-occupancy lane or free parking. Likewise, Horne, Jaccard, and Tiedemann (2005) found that simulated policies such as carbon taxes, gasoline vehicle disincentives, and single occupancy vehicle disincentives assist in motivating technological change, which eventually will force adoption by consumers. In a latest study conducted by $\mathrm{Li}$ and colleagues (2013), the authors show different factors leading up to different preferences for buying flexible fuel and hybrid electric vehicles. The results show that consumers who have higher income and higher opportunity cost of time will not prefer buying AFVs because the lower energy content of flexible fuel will require frequent refueling and thus increase the length of travel time. They also find that as income increases, consumers' willingness to buy AFVs reduces, causing an inverse relation between consumer preference for AFVs and household income; consumers who own hybrid electric cars have a lower probability of buying AFVs.

Although the last couple of decades has witnessed persistent effort by the United States government to enhance ethanol production and promote ethanol blended gasoline as an alternative transportation fuel (Chaudhuri, Tonsor and Peterson 2011), research focusing on flexible fuels is limited in the United States. We are in agreement with the literature that fuel availability remains a major concern for buying alternative-fuel vehicles. This suggests that it is important for researchers to dig deeper to understand how different types and levels of pricing of flexible transportation fuels impact consumers' WTP.

\section{SAMPLING AND METHODOLOGY}

The literature indicates that examination of consumer heterogeneity may be difficult in a random utility model, since individual characteristics tend to be constant among a set of choices (Boxall and Adamowicz 2002). Thus, complete understanding of heterogeneity in the demand analysis requires a priori knowledge of possible sources of heterogeneity over and above sociodemographic information (Swait 1994). In particular, consumers' attitudes, perception, past experience, and the influence of society are some of the critical factors that may lead to heterogeneity in preference patterns (McFadden 1986). Latent class modeling aids in understanding systematic heterogeneity in consumers' preference structure by considering these explanators of heterogeneity while constructing latent classes or segments (Boxall and Adamowicz 2002). The approach assumes that consumers can be grouped into discrete segments where each segment is characterized by homogenous preferences, while preferences are heterogeneous across segments (Swait 1994). The model simultaneously assesses the influence of latent variables such as attitudes or perceptions, socioeconomic effects, and choice-based attributes in the estimation of the latent segments and predicting product choice (McFadden 1986; Swait 1994).

Choice experiments typically require respondents to choose an alternative among several product profiles, each defined by an attribute set. Traditionally, choice data are modeled utilizing Multinomial Logit (MNL), Nested MNL, and Probit models (Swait and Adamowicz 2001). However, each of these models suffers from several shortcomings. The MNL has an error structure assuming Independence from Irrelevant Alternatives (IIA). The IIA property states that "the relative odds of one alternative being chosen over a second should be independent of the presence or absence of unchosen third alternatives" (McFadden 1974). Moreover, the conventional MNL assumes homogeneity in consumer preference; that is, all respondents have the identical preference structure across alternative fuel attributes (Lusk, Roosen, and Fox 2003). Latent class modeling is an improvement over these models, since it is void of such restrictive assumptions (Boxall and Adamowicz 2002).

Following Greene and Hensher (2003), we use a latent segmentation model to analyze consumer preference heterogeneity for alternative transportation fuel in the U.S. using an Internet-based survey and employing choice-based 
conjoint analysis. Web-based adaptive conjoint analysis (ACA) methods adjust the design of the following conjoint questions based on a consumer's response to previous questions, as opposed to the static consumer response typically obtained by traditional nonadaptive or fixed design. ACA also yields relatively quick and iterative feedback on the customers' preference structure.

\section{MODEL OF FUEL CHOICE}

Random utility models are based upon the assumption that individual $i$ derives utility $U_{i j}\left(X_{i j}\right)$ from selecting option $j$ where $X_{i j}$ is a vector of attributes of $j$ as perceived by individual $i$. The utility function, $U_{i j}\left(X_{i j}\right)$ is composed of two components, the deterministic component that depends on the attributes of the alternatives $V_{i j}\left(X_{i j}\right)$ and the random component represented by the error term, $\varepsilon_{i j}$ :

$$
U_{i j}=V_{i j}\left(X_{i j}\right)+\varepsilon_{i j}
$$

In this study, $V_{i j}$ is the systematic portion of the utility function determined by the alternative fuel attributes and their levels:

$$
\begin{gathered}
V_{i j}=\beta_{i} X_{i j} \forall j=A, B, C \\
V_{i j}=\delta \quad \forall j=D
\end{gathered}
$$

where $X_{i j}$ is the vector of choice attributes; A, B, and $\mathrm{C}$ are alternative choices available to the consumer; D refers to the option of not purchasing either of the three alternatives; and $\delta$ is a constant. The attributes $\left(X_{i j}\right)$ considered in the analysis are fuel cost and availability, level of emission, purchase and maintenance costs, and whether it is biofeedstock.

The latent class approach assumes that latent variables such as general attitudes, perceptions, and observable variables such as sociodemographic characteristics influence segment membership and classifies the respondent into one of the $S$ segments (Swait 1994). The probability that a randomly chosen individual $i$ chooses $j$ and lies in segment $s$ where $s=1, \ldots, S$ is given by (McFadden 1974; Swait 1994):

$$
\begin{aligned}
\pi_{i}(j)= & \sum_{s=1}^{S}\left[\frac{\exp \left(\alpha \lambda_{s} Z_{i}\right)}{\sum_{s=1}^{S} \exp \left(\alpha \lambda_{s} Z_{i}\right)}\right] * \\
& {\left[\frac{\exp \left({ }_{s} \beta_{s} X_{i j}\right)}{\sum_{j \in A, B, C, D} \exp \left({ }_{s} \beta_{s} X_{i j}\right)}\right] }
\end{aligned}
$$

where the first expression gives the probability of membership for respondent $i$ in segment $s$ (i.e., $\pi_{i s}$ ), and the second expression gives the choice probabilities conditional on segment membership (i.e., $\left.\pi_{i \mid s}(j)\right)$. Additionally, $\alpha$ is a scale factor, $\mu_{s}$ and $\beta_{s}$ are segment-specific scale and utility parameters respectively, and $\lambda_{s}$ are segment membership parameters. Note that in this model, the scale parameter $\mu$ is set to unity. $Z_{i}$ is a vector of both the sociodemographic variables as well as latent characteristics. Sociodemographic characteristics used in this analysis are gender, age, level of education, income, employment, race, family size, state of residency, vehicle characteristics, and willingness to buy a flex fuel vehicle (FFV) in the next five years. This model permits choice attribute data and individual respondent characteristics to simultaneously explain consumer's choice behavior. Additionally, latent class approaches do not make any restrictive assumptions regarding distribution of parameters across individuals (i.e., normality need not be assumed). The parameters $\left(\lambda_{s}, \beta_{s}, \mu_{s}, \alpha\right)$ are estimated via the maximum likelihood method.

$$
\begin{aligned}
\ln L(\alpha, \beta \mid S)= & \sum_{i=1}^{N} \sum_{\forall m} \sum_{j \in A, B, C, D} \delta_{i j} \ln \\
& \left(\sum_{s=1}^{S} \pi_{i \mid s}(j)^{*} \pi_{i s}\right)
\end{aligned}
$$

Equation (5) gives the log likelihood function where $N$ is the total number of respondents who participated in the survey, $m$ represents the total number of choice sets per person for which the choice data were provided, jrepresents the alternatives from the choice experiment, and $\delta_{i j}$ equals 1 if individual $i$ 
chooses $j$ and 0 otherwise (Boxall and Adamowicz 2002).

\section{Research Design}

Our unique consideration of cellulosic biomass-based fuel, which is currently not available to consumers, necessitates the use of hypothetical choice experiments. A questionnaire was developed that focused on respondents' degree of awareness, attitude toward, and perception of bio-fuel-related issues. The sociodemographic characteristics include age, gender, education, annual income, number of adults and children in the family, state of residency, vehicle characteristics, average number of miles driven annually, and average fuel cost incurred.

Additional information was collected and used in the latent segment model. This involved a series of 22 motivational statements (appendix A) indicating reasons why respondents may favor the usage of ethanol as an alternative fuel based on environmental issues with reference to air pollution, level of GHG emission, and probable effects on climate change, deforestation, and loss of grasslands. Other issues considered were the effect of production of corn-based ethanol on the local economy in terms of job creation, income generation, and opportunity for corn farmers. Respondents were required to rate the degree of importance of each statement on a 5-point Likert type scale ranging from 1 (strongly agree) to 5 (strongly disagree) (Beard and Ragheb 1983). We subsequently used exploratory factor analysis to analyze the scores of the respondents to measure consumers' attitude toward consumption of ethanol as an alternative transportation fuel.

\section{Attributes of Alternative Fuels and Their Levels}

The second part of the survey was an application of a choice experiment where respondents indicate their choices among sets of alternative transportation fuels or opting out from choosing any of these products (Alfnes
2004). We personalized the survey to include choice experiments revealing resident preferences for alternative transportation fuels based on information provided by respondents (i.e., car type, miles driven per year, purchase/lease status) earlier in the survey. Table 2 lists the attribute-level specification for the alternative fuel choice experiment.

Fuel cost refers to the total annual cost of buying transportation fuel. It is a function of fuel per gallon prices, fuel efficiency, and the average number of miles driven by the respondent annually. Price of fuel per gallon indicates the price of the transportation fuel per gallon. Fuel efficiency refers to the energy content/ mileage per gallon of alternative transportation fuels.

1. Fuel availability: Fuel availability is defined as the percentage of existing gas stations that also offer alternative fuels over and above its supply of conventional gasoline in the area (Potoglou and Kanaroglou 2007). In this study, it is measured by the percentage of gas stations offering the alternatives within a five-mile radius from the respondents' residence.

2. Level of pollution and GHG emissions indicates the amount of airborne pollutants emitted by the vehicles and the level of GHG released, in terms of the annual tons of $\mathrm{CO}_{2}$, on combustion of given volume of ethanolblended gasoline as compared to conventional gasoline. Emission of airborne pollutants and GHG is injurious for health and produces smog.

3. Feedstock: Feedstock indicates the basic ingredient from which the alternative transportation fuel is derived. Currently, ethanol used in the commercial sector is predominantly corn based. Agricultural plant wastes, such as sugarcane bagasse, cereal straws, and corn stover; plant wastes from industrial processes, such as paper pulp and sawdust; and energy crops used for fuel production, such as switchgrass, provide the basic feedstock for cellulosic ethanol (Moller 2005).

4. Cost of buying and maintaining FFV: This attribute refers to the purchase price of a FFV, annual repair, and maintenance cost. 
TABLE 2. Attributes and Levels of Alternative Fuel Choice Experiment

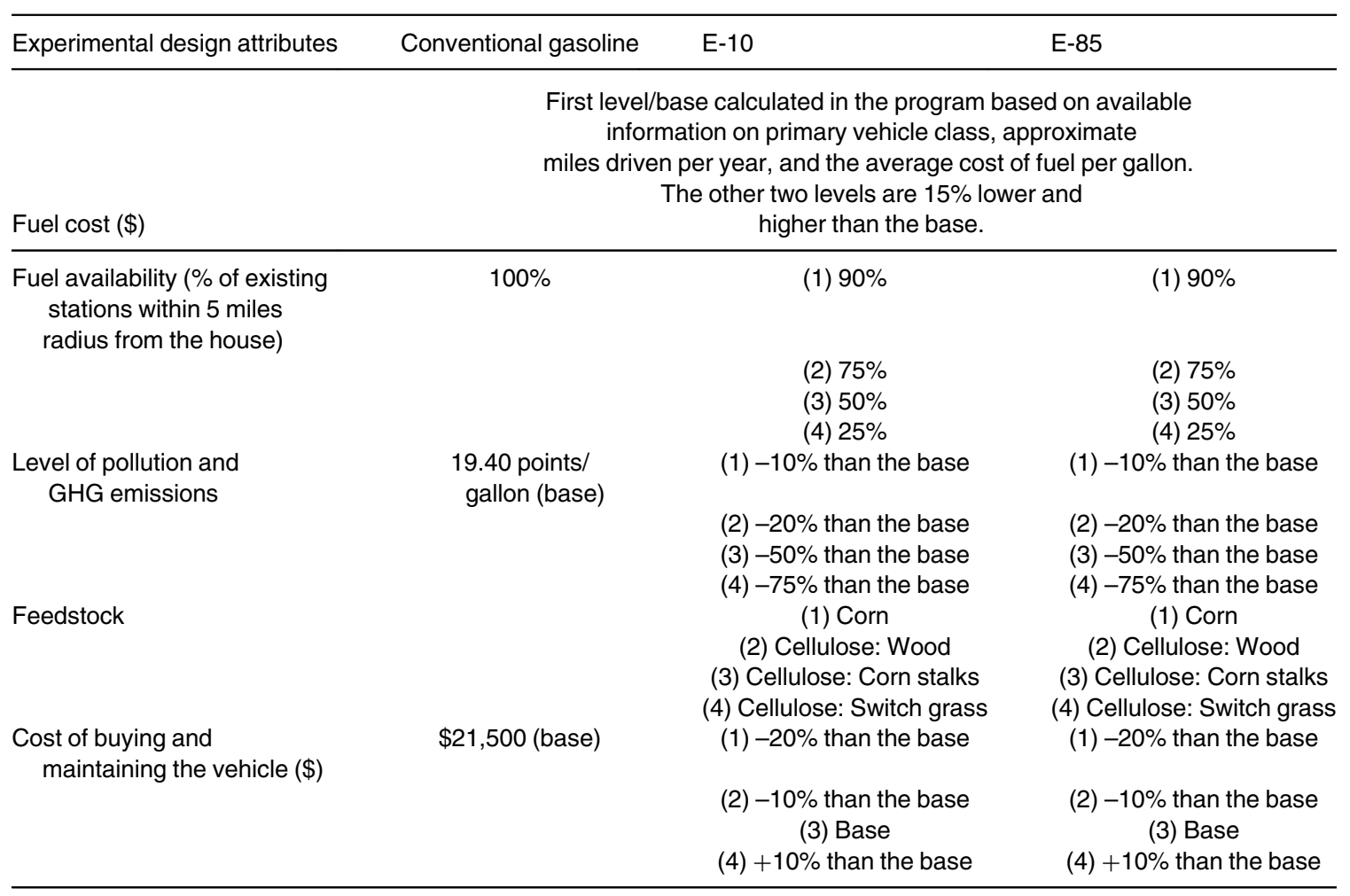

\section{Survey Implementation}

Web-based surveys are an increasingly popular means to conduct research and, particularly in the U.S., are becoming conventional market research tools. Typical Internet-based surveys usually suffer from self-selection bias, given the nonrepresentative nature of the population with access to the Internet (Eysenbach and Wyatt 2002). Thus, in survey preparation, we took special care to follow Wyatt's (2000) guidelines to improve the validity and reliability of data and avoid potential selection bias. Following Gao and Schroeder (2009), e-Rewards, Inc., a marketing research company, conducted an Internet-based survey and collected complete responses from 1,400 U.S. residents with a $68 \%$ response rate in January 2009.

Table 3 gives the descriptive profile of respondents versus the 2000 U.S. Census.

Table 4 reports pair-wise correlation between the sociodemographic variables. The highest negative correlation among the exogenous variables was .416 between "age" and "employment," and the highest positive correlation was .318 between "income" and "education"-significant at the $10 \%$ level of significance or higher.

\section{EMPIRICAL SPECIFICATION}

In the current choice experiment, a typical choice scenario (table 1) consisted of four alternatives. The first three choices present the respondent with multiple sets of hypothetical alternative transportation fuels and vehicle choices, the underlying assumption being that standard vehicles run on conventional gasoline or E-10 whereas FFVs have the choice of running on gasoline, E-10, or E-85. The fourth choice gives the respondents a choice to opt out. The five control variables (i.e., fuel cost, fuel availability, emission, bio-feedstock, cost of buying and maintaining the vehicle) and their possible settings are shown in table 2. According to the research design, conventional 
TABLE 3. Descriptive Statistics

\begin{tabular}{|c|c|c|}
\hline & Survey data statistics & 2000 U.S. census \\
\hline \multicolumn{3}{|l|}{ Gender } \\
\hline Females & 46.49 & 49.1 \\
\hline Males & 53.51 & 50.9 \\
\hline \multicolumn{3}{|l|}{ Age } \\
\hline 20 years and less & 1.21 & 28.6 \\
\hline $21-30$ years & 15.83 & 13.63 \\
\hline $31-40$ years & 16.96 & 15.36 \\
\hline $41-50$ years & 14.55 & 15.11 \\
\hline $51-60$ years & 12.99 & 11.03 \\
\hline $61-70$ years & 27.04 & 7.23 \\
\hline $71-80$ years & 10.93 & 5.78 \\
\hline 81 years and over & 0.5 & 3.26 \\
\hline \multicolumn{3}{|l|}{ Income } \\
\hline Less than $\$ 20,000$ & 12.63 & 22.1 \\
\hline$\$ 20,000$ to $\$ 39,999$ & 25.05 & 25.29 \\
\hline$\$ 40,000$ to $\$ 59,999$ & 22.07 & 19.66 \\
\hline$\$ 60,000$ to $\$ 79,999$ & 14.83 & 13.34 \\
\hline$\$ 80,000$ to $\$ 99,999$ & 9.3 & 8.37 \\
\hline$\$ 100,000$ to $\$ 119,999$ & 4.9 & 11.24 \\
\hline$\$ 120,000$ to $\$ 139,999$ & 2.91 & \\
\hline$\$ 140,000$ to $\$ 159,999$ & 2.63 & \\
\hline$\$ 160,000$ to $\$ 179,999$ & 1.49 & \\
\hline$\$ 180,000$ or more & 4.19 & \\
\hline \multicolumn{3}{|l|}{ Education } \\
\hline Did not graduate from high school & 0.78 & 19.6 \\
\hline Graduated from high school, did not attend college & 14.48 & 28.6 \\
\hline Attended college, no degree earned & 23.85 & 21.1 \\
\hline Attended college, associates or trade degree earned & 127 & 6.3 \\
\hline Attended college, bachelor's degree earned & 28.46 & 15.5 \\
\hline Graduate or advanced degree (MS, MA, PhD, Law) & 17.89 & 8.9 \\
\hline Mexican/Latino & 6.81 & 12.5 \\
\hline Other & 1.85 & - \\
\hline \multicolumn{3}{|l|}{ Race } \\
\hline White/Caucasian & 80.27 & 75.1 \\
\hline Black/African American & 9.01 & 12.3 \\
\hline Asian/Pacific Islander & 1.49 & 3.7 \\
\hline American Indian & 0.21 & 0.9 \\
\hline Mexican/Latino & 6.81 & 12.5 \\
\hline Other & 2.2 & - \\
\hline \multicolumn{3}{|l|}{ Employment } \\
\hline Full-time employed & 44.22 & \\
\hline Part-time employed & 10.5 & 63.9 \\
\hline Unemployed & 4.26 & 36.1 \\
\hline House maker & 4.12 & \\
\hline Retired & 30.02 & \\
\hline Student & 4.47 & \\
\hline Other & 2.41 & \\
\hline
\end{tabular}

Source: U.S. Census 2000; Total number of household respondents $(1,400)$.

gasoline constituted the base alternative where the levels of the attributes are being held constant. Moreover, fuel cost is the only control variable that is assumed to vary across all respondents. Attributes for the second and third alternatives (i.e., E-10 and E-85) vary in the design. Instead of running all $3^{3} \times 2^{4} \times 2^{4} \times 2^{4} \times 2^{4}$ combinations of factors with each factor containing a different number of levels, we used the PLAN and OPTEX procedures in SAS to identify a choice design maximizing the D-efficiency scores (Kuhfeld 2005; 
TABLE 4. Correlation Between Sociodemographic Variables

\begin{tabular}{lccccccc}
\hline & Age & Income & Education & Female & No. of adults in household & Employment & White \\
\hline Age & 1.000 & $0.063^{\star *}$ & -0.083 & -0.013 & $-0.176^{\star \star *}$ & $-0.416^{*}$ & 0.134 \\
Income & & 1.000 & $0.318^{\star \star *}$ & $-0.062^{*}$ & $0.152^{\star *}$ & $0.166^{\star \star *}$ & 0.014 \\
Education & & & 1.000 & -0.044 & 0.006 & $0.110^{\star \star *}$ & -0.020 \\
Female & & & & 1.000 & $-0.047^{\star}$ & $-0.081^{\star *}$ & -0.042 \\
No. of adults in household & & & & & 1.000 & $0.048^{*}$ & $-0.066^{\star}$ \\
Employment & & & & & & 1.000 & $0.099^{\star \star \star}$ \\
White & & & & & & 1.000 \\
\hline
\end{tabular}

${ }^{\star \star *} 1 \%$ level of significance ; ${ }^{\star *} 5 \%$ level; ${ }^{*} 10 \%$ level.

Lusk and Norwood 2005). The final choice design has 31 choice sets randomly assigned into four blocks each consisting of $8,8,8$, and 7 choice exercises respectively. Each block with limited choice exercises helped to keep the task for respondents simple and reasonable and prevent possible fatigue effects (Savage and Waldman 2008). We also randomized the order of choice sets to alleviate any ordering impacts (Loureiro and Umberger 2007).

\section{Estimation of the Number of Latent Segments}

A total of 1,400 respondents answered all the demographic questions. However, out of this pool, only 620 respondents answered the questions related to the alternative transportation fuel choice experiment. There were four blocks of choice sets randomly assigned to the respondents, each consisting of eight, eight, eight, and seven choice exercises. More specifically, 552 respondents were assigned blocks of eight choice exercises, and 68 respondents were assigned blocks of seven choice exercises, thereby generating 4,892 data points.

We used statistical criteria to select the optimal number of segments to be employed in the latent segmentation analysis (table 5). This is critical, since specifying too few segments tends to ignore the interclass differences. Likewise, specifying too many segments may result in an unstable model. While the value of loglikelihood (LL) is directly proportional to the number of segments used in the analysis, the minimum Bayesian Information Criterion (BIC) value suggests that the four-class solution is the best of the six estimated models (Allenby 1990; Boxall and Adamowicz 2002).

\section{Willingness-to-Pay Estimates}

We observe a rising trend in the literature measuring consumers' willingness to pay (WTP) for product attributes using choice-based conjoint analysis. Veisten (2007) investigates consumers'

TABLE 5. Information on the Converged Latent Segment Models ${ }^{a}$

\begin{tabular}{lcccccccc}
\hline & $\begin{array}{c}\text { Log likelihood at } \\
\text { convergence }(\mathrm{LL})\end{array}$ & $\begin{array}{c}\mathrm{BIC} \\
(\mathrm{LL})^{\mathrm{b}}\end{array}$ & $\begin{array}{c}\text { CAIC } \\
(\mathrm{LL}){ }^{\mathrm{c}}\end{array}$ & $\mathrm{L}^{2}$ & $d^{\mathrm{d}}$ & $\mathrm{CAIC}^{\left(\mathrm{L}^{2}\right)^{\mathrm{e}}}$ & $\begin{array}{c}\text { Classification } \\
\text { error }^{2}\end{array}$ & $\mathrm{R}^{2}$ \\
\hline Model 1 & -2356.7057 & 4793.6866 & 4805.6866 & 4713.4114 & 792 & -1376.7512 & 0 & 0.0058 \\
Model 2 & -1996.5683 & 4294.1686 & 4339.1686 & 3993.1366 & 759 & -1843.2692 & 0.0084 & 0.3674 \\
Model 3 & -1765.4663 & 4052.7213 & 4130.7213 & 3550.9326 & 726 & -2051.7165 & 0.0312 & 0.4599 \\
Model 4 & -1359.0318 & 3460.6092 & 3571.6092 & 2718.0637 & 693 & -2610.8286 & 0.0419 & 0.4951 \\
Model 5 & -1332.9835 & 3629.2692 & 3773.2692 & 2665.9669 & 660 & -2409.1686 & 0.0802 & 0.5003 \\
Model 6 & -1614.6659 & 4413.3908 & 4590.3908 & 3229.3317 & 627 & -1592.047 & 0.0654 & 0.4982 \\
\hline
\end{tabular}

asample size is 4,892 choices from 620 individuals $(N)$.

${ }^{b} \mathrm{BIC}$ : Bayesian Information Criterion.

${ }^{\mathrm{c} C A I C}$ (LL): Constant Akaike Information Criterion based on log-likelihood (LL).

${ }^{\mathrm{d}}$ Degrees of freedom.

${ }^{e}$ Consistent Akaike Information Criterion based on L-squared. 
WTP for an environmental attribute through certification and eco-labeling using conjoint analysis. Next, he employs open-ended contingent valuation to tease out the difference between consumers' preference for product attributes visà-vis their valuation for the whole-product. Louviere and Islam (2008) compares and contrasts estimates from choice-based conjoint with that of constant sum scales and best-worst scaling while measuring the importance of product attributes and consumers' WTP.

Following Lusk and colleagues (2003), we quantify the value that consumers place on each of the fuel-vehicle attributes (i.e., consumer's WTP estimates) by taking the ratio of the attribute coefficients to purchase and maintenance cost coefficient. We utilized simulation techniques to generate 20,000 values of each WTP estimate using a bootstrapping procedure to determine statistical variability in parameter estimates (Krinsky and Robb, 1986). Specifically, 20,000 observations were drawn from a multivariate normal distribution parameterized by using the coefficients and estimated variance-covariance matrix. The simulated WTP statistics from the MNL model and the four segments of the LCM were employed to empirically test for variation in WTP preferences across segments. First, we estimated mean WTP and corresponding 95\% confidence intervals to incorporate both statistical and preference variability in LCM. We repeat similar simulation procedure to obtain the mean WTP estimates and $95 \%$ confidence intervals for the MNL model.

We employ the utility estimates to examine how restricted alternative-fuel choice sets affect consumer welfare. With the exception of conventional gasoline, the choice experiment involves four different attribute levels for biofeedstock: corn grain ethanol and ethanol derived from three sources of cellulosic biomass (i.e., wood, corn stalks, and switch grass). We estimate welfare impacts of government policies under the following three scenarios: conventional gasoline not available, government mandates banning the usage of corn-grain ethanol, and cellulosic ethanol is not available for mass consumption. Following Small and Rosen (1981), expected maximum utility (EU) from consumeri $i$ s choice set selection is given by:

$$
E U_{i}=\ln \left(\sum_{j} \exp \left(V_{i j}\right)\right)+K
$$

where $K$ is Euler's constant and $V_{i j}$ is defined by equations (2) and (3). Under the assumption of no income effects, general welfare changes may be given by:

$$
C V_{i}=\frac{1}{\gamma}\left[\ln \left(\sum_{j} \exp \left(V_{i j}^{1}\right)\right)-\ln \left(\sum_{j} \exp \left(V_{i j}^{0}\right)\right)\right]
$$

where $C V_{i}$ is the compensating variation for individual $i, \gamma$ is the marginal utility of income, the 0subscript refers to the initial state, and 1 superscript refers to the new state following some change in $V_{i j}$ (Boxall and Adamowicz 2002; Hanemann 1982).

\section{RESULTS AND DISCUSSION}

\section{Factor Analysis}

We hypothesized that four factors encompass consumers' perception of production and usage of ethanol as alternative transportation fuel contingent on the 22 statements indicating respondents' motivational indicators. We name the first component "Economic and environmental effect" with the conjecture that motivational statements involving economic and environmental impact of production and usage of ethanol on the U.S. economy will load significantly more on this factor. The second factor has been labeled "Government's financial support towards ethanol industry" under the assumption that the motivational statements involving government's financial support for the ethanol/ biofuel industry that impacts the local economy, the corn farmers, and reduces the country's dependency on foreign oil will load highly in this factor. Motivational statements concerning the effect of production of corn-based ethanol on food price volatility, deforestation, and climate change food supply and food price volatility is expected to load heavily on the third factor. This factor has been labeled "Impact of 
biofuel production on ecology and food." Finally, we label the fourth factor as "Economical consequence of shift in demand of corn for ethanol production" under the hypothesis that statements under this factor relate to the shift in production of corn serving human needs and as cattle feed to production of ethanol and economic consequences. We conducted confirmatory factor analysis (CFA), which tests factor structure with measurement hypotheses as well as establishes a logical basis for nomolgical validity (Bagozzi and Yi 1990; 1991). Please refer to appendix A for the labels of the components. Note that corresponding to each factor loading, we report the standard error in parentheses, indicating level of significance. Findings indicate that with three or more indicators load on each factor with corresponding factor loadings was greater than 0.4 . We also report the fit statistics in appendix B. Next, we calculate the scores of the four latent factors for each respondent in the sample. The score estimates were subsequently included in the $Z_{i}$ vector in equation (4), to explain latent segment membership.

\section{Characterizing the Segments and Comparing the Models}

We analyze the latent class model using Latent GOLD software. Consistent with the existing literature, we use decision choice of the respondents as the dependent variables (Vermunt 2007; Vermunt and Magidson 2008). Fuel cost, fuel availability, level of emission, purchase and maintenance costs, and corn grain- and cellulosic-ethanol as the alternative transportation fuels are used in the model. We also include gender, age, annual pretax household income, and geographic location as controls for sociodemographic factors. Additionally, access to multilevel responses for each respondent provides us access to multilevel observations.

The utility function parameters for the MNL model and the 4-segments LCM are displayed in table 6 . The basis of many latent variable processes is tested by means of nonparametric method. Researchers often employ test statistics such as Wald chi-square or Pearson deviance to show which models are best considering fit and degrees of freedom (Muthén and Muthén 2001). We report Wald test statistics (Wald 1943) indicating the joint significance of several coefficients, namely, influence of fuel attributes determining latent class segmentation of consumers. Findings suggest that in the LCM, with the exception of "fuel cost," the rest of the fuel attributes exhibit pronounced impact across the different class of segments, significant at $1 \%$ level of significance.

We label the segments based on their preferences (e.g., utility coefficients) presented in the table. Segment one was labeled "corn-based ethanol rejecter" since the respondents who belong to this segment exhibit disutility from the consumption of ethanol derived from either corn grain or corn stalk. However, these members exhibit low utility from the consumption of ethanol from biomass, specifically wood and switch grass, effect significant at $1 \%$ level of significance. They also exhibit preference for lower emission levels and lower fuel availability, significant at $1 \%$ of level of significance. We label the second segment as "confused but concerned" since members who belong to this segment exhibit contradictory preference structure. Specifically, they have preference for both corn grain and corn stalk ethanol, but they derive disutility from the consumption of ethanol derived from any other biomass, significant at $1 \%$ level of significance. Additionally, the members exhibit preference for lower fuel availability, higher level of emissions, and higher purchase and maintenance costs, significant at $1 \%$ of level of significance. Segment three has been labeled "cellulosic ethanol acceptor" since the members in this segment exhibit utility from the consumption of cellulosic ethanol (i.e., ethanol derived from wood, corn stalks, switch grass, etc.). These members also exhibit strong disutility from the use of corn grain ethanol. They exhibit preference for higher fuel availability and lower emission levels, significant at $1 \%$ of level of significance. Consumption of corn grain ethanol as well as cellulosic ethanol imparts positive utility to members belonging to the fourth segment. Thus, the last segment has been termed as "ethanol enthusiast." These consumers also 


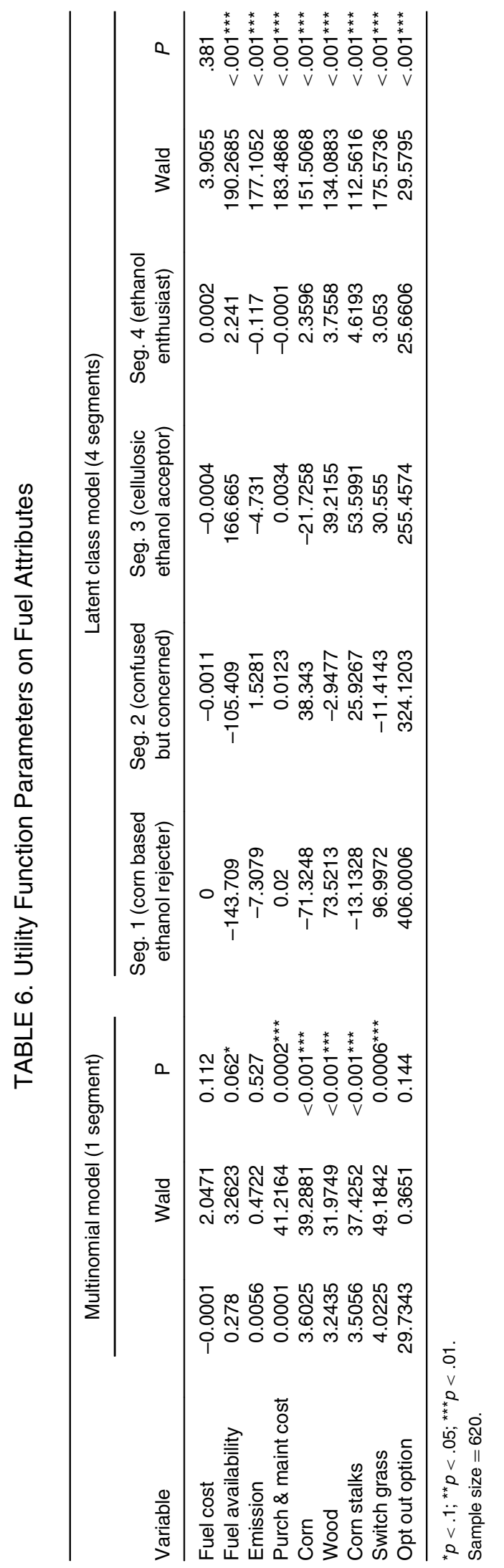


show significant preference for lower emission levels, purchase and maintenance costs, and higher fuel availability.

The latent class four-segment model depicts the variation in consumer preference across fuel attributes, an aspect not captured by a single-segment MNL model. Parameters for fuel availability are positive and statistically significant across the MNL model and "cellulosic ethanol acceptor" (segment 3) and "ethanol enthusiast" (segment 4) members of the foursegment model. Consistent with extant literature (Potoglou and Kanaroglou 2007), this indicates that members who belong to these segments derive utility from higher fuel availability. Interestingly, members of "corn-based ethanol rejecter" (segment 1) and "confused but concerned" (segment 2) exhibit preference for lower fuel availability. Similarly, parameters for level of emission are negative and statistically significant for the "corn-based ethanol rejecter" (segment 1), "cellulosic ethanol acceptor" (segment 3), and "ethanol enthusiast" (segment 4) members of the four-segment model. The corresponding parameter in the MNL model indicates that respondents are indifferent toward level of emission.

Comparing utility function parameters for the different ethanol sources against the MNL model and the four-segment model reveals preference heterogeneity across consumers. According to the MNL model, members derive positive utility from the consumption of ethanol as an alternative fuel, irrespective of the source of ethanol. This result is consistent with "ethanol enthusiast" (segment 4) members in the four-segment model. Furthermore, preference for corn grain- and cellulosic-ethanol varies significantly across the other three segments. Findings also indicate that respondents are indifferent toward fuel cost in both the MNL and the four-segment model.

Segment membership variables, specifically the sociodemographic characteristics across the four segments in the latent class model are displayed in table 7. The first row of table 7 reports class sizes, with the segments being ordered in descending order of their size. Segment 1 contains approximately $47.58 \%$ of the total 1,400 respondents, segment 2 contains about $23.3 \%$, and segments 3 and 4 contain approximately $15.37 \%$ and $13.75 \%$ of the respondents respectively.

We report Wald test statistics along with the corresponding $p$ value to indicate the joint significance of a subset of coefficients, namely, influence of sociodemographic variables on latent class segmentation. Results based on the segment

TABLE 7. Segment Membership Variables for the Four-Segment Model

\begin{tabular}{|c|c|c|c|c|c|c|}
\hline Variables & $\begin{array}{l}\text { Seg. } 1 \text { (corn-based } \\
\text { ethanol rejecter) }\end{array}$ & $\begin{array}{l}\text { Seg. } 2 \text { (confused } \\
\text { but concerned) }\end{array}$ & $\begin{array}{l}\text { Seg. } 3 \text { (cellulosic } \\
\text { ethanol acceptor) }\end{array}$ & $\begin{array}{l}\text { Seg. } 4 \text { (ethanol } \\
\text { enthusiast) }\end{array}$ & Wald & $P$ \\
\hline Class size & 0.4758 & 0.233 & 0.1537 & 0.1375 & & \\
\hline Intercept & 1.0817 & -2.2161 & 1.5169 & -0.3826 & 0.671 & .88 \\
\hline \multicolumn{7}{|l|}{ Gender } \\
\hline Female & 0.108 & -0.0008 & -0.0373 & -0.0699 & 2.647 & .45 \\
\hline Male & -0.108 & 0.0008 & 0.0373 & 0.0699 & & \\
\hline \multicolumn{7}{|l|}{ Age } \\
\hline $16-24$ & 0.0547 & 0.0041 & -0.0457 & -0.013 & 29.218 & $.046^{\star \star}$ \\
\hline $25-34$ & 0.0132 & -0.2388 & -0.3873 & 0.6129 & & \\
\hline $35-44$ & -0.4071 & -0.0834 & 0.2733 & 0.2172 & & \\
\hline $45-54$ & 0.4692 & -0.0229 & 0.0308 & -0.4771 & & \\
\hline $55-64$ & -0.0254 & 0.0821 & 0.3198 & -0.3765 & & \\
\hline $65-74$ & -0.0245 & 0.2525 & -0.0738 & -0.1542 & & \\
\hline $75-80$ & -0.0801 & 0.0063 & -0.117 & 0.1907 & & \\
\hline \multicolumn{7}{|c|}{ Geographic location } \\
\hline Calif. & -0.294 & 2.0734 & -1.1554 & -0.624 & 9.514 & $.023^{\star *}$ \\
\hline Not Calif. & 0.294 & -2.0734 & 1.1554 & 0.624 & & \\
\hline
\end{tabular}

${ }^{\star} p<.1 ;{ }^{* \star} p<.05 ;{ }^{* \star *} p<.01$.

Sample size $=620$. 
membership variables indicate that relatively young respondents (i.e., 16 to 34 years of age) are more likely to fall under the "corn-based ethanol rejecter" segment (segment 1) and less likely to belong to "cellulosic ethanol acceptor" segment (segment 3 ) relative to other respondents in our sample. The remaining coefficients that indicate the degree of influence of the corresponding variable on consumers' preference structure may be interpreted accordingly.

Historically, California has been the pioneer of administrative innovations (Audretsch and Feldman 1996). For instance, the California Air Resources Board (CARB) initiated the ZeroEmission Vehicle (ZEV) program as early as 1990 with the objective of significantly reducing emission from passenger fleet vehicles (Summers, Skowron, and Miller, 1993). Bunch and colleagues (1993) used discrete-choice nested MNL models for vehicle choice and binomial logit models for fuel choice to determine derived demand for clean-fuel vehicles in California. Consistent with the existing literature, we dichotomized geographic location as an important factor between California versus Non-California. Results indicate that state of residency, specifically whether the respondent is from California, has a significant impact on the decision choice made by the respondent. Consumers who reside in California are more likely to reject ethanol, irrespective of its source relative to other respondents, effect significant at 5\% level of significance. Two most important characteristics of alternative transportation fuel are reduced gas efficiency and low availability. The general high cost of living and long commute (due to traffic or/ and distance) make usage of alternative transportation fuel an added expense for the residents of California. Thus, overall, they are adverse toward adoption of alternative transportation fuels. Furthermore, results indicate that gender and annual household income do not have statistically significant influences on member segmentation.

\section{Willingness-To-Pay Estimates}

Table 8 presents the willingness to pay (WTP) estimates and the corresponding 95\% confidence intervals for fuel attributes. The estimates indicate consumer's WTP for the fuel attributes relative to purchase and maintenance costs. Since we utilized three levels for the product attribute "fuel cost," but the other product attributes have four levels, we adjusted effects coding accordingly to adjust the relative value contribution over a consistent base (Boxall and MacNab, 2000; Bech and Gyrd-Hansen, 2005). We report $95 \%$ confidence interval (CI) in the bracket.

The MNL estimates reveal that consumers are indifferent toward fuel cost, fuel availability, and emissiovn level, and are not willing to pay to make a switch from conventional gasoline to alternative transportation fuels. Specifically, a representative consumer is willing to pay $\$ 72,050.00, \$ 64,870.00, \$ 70,112.00$, and $\$ 80,450.00$ less in purchase and maintenance costs for vehicles run on corn grain-, wood-, corn stalks-, and switch grass-based ethanol respectively relative to conventional gasoline. Even though the estimated premiums appear large and reflect some exaggeration of WTP in a hypothetical setting, we can be confident regarding their relative magnitudes under the assumption that hypothetical bias exists and is relatively similar across attributes (Cummings, Harrison and Rutström 1995; Lusk et al. 2001).

Examining preference heterogeneity using a latent class model lays out more intricate details. The latent class model estimates indicate that "corn-based ethanol rejecter" (segment 1) and "confused but concerned" (segment 2) members are willing to pay $\$ 7,185.46$ (95\% CI $=7,077.6$ to 7,297 ) and $\$ 8,569.80$ (95\% CI $=6,499.1$ to 12,569 ) more in purchase and maintenance fees for $100 \%$ increase in availability of alternative fuels in the existing gas stations within 5 miles radius from their respective residence respectively. On the contrary, "cellulosic ethanol acceptor" (segment 3) members are willing to pay $\$ 49,019.12$ (95\% CI $=-49,679$ to $-48,351)$ less in purchase and maintenance fees for higher fuel availability. Interestingly, even though "ethanol enthusiast" (segment 4) members exhibit highest WTP estimates of $\$ 22410.00(95 \% \mathrm{CI}=-1.63 \mathrm{E}+05$ to $2.09 \mathrm{E}$ $+05)$, the estimate is not statistically significant since the $95 \%$ confidence interval includes 


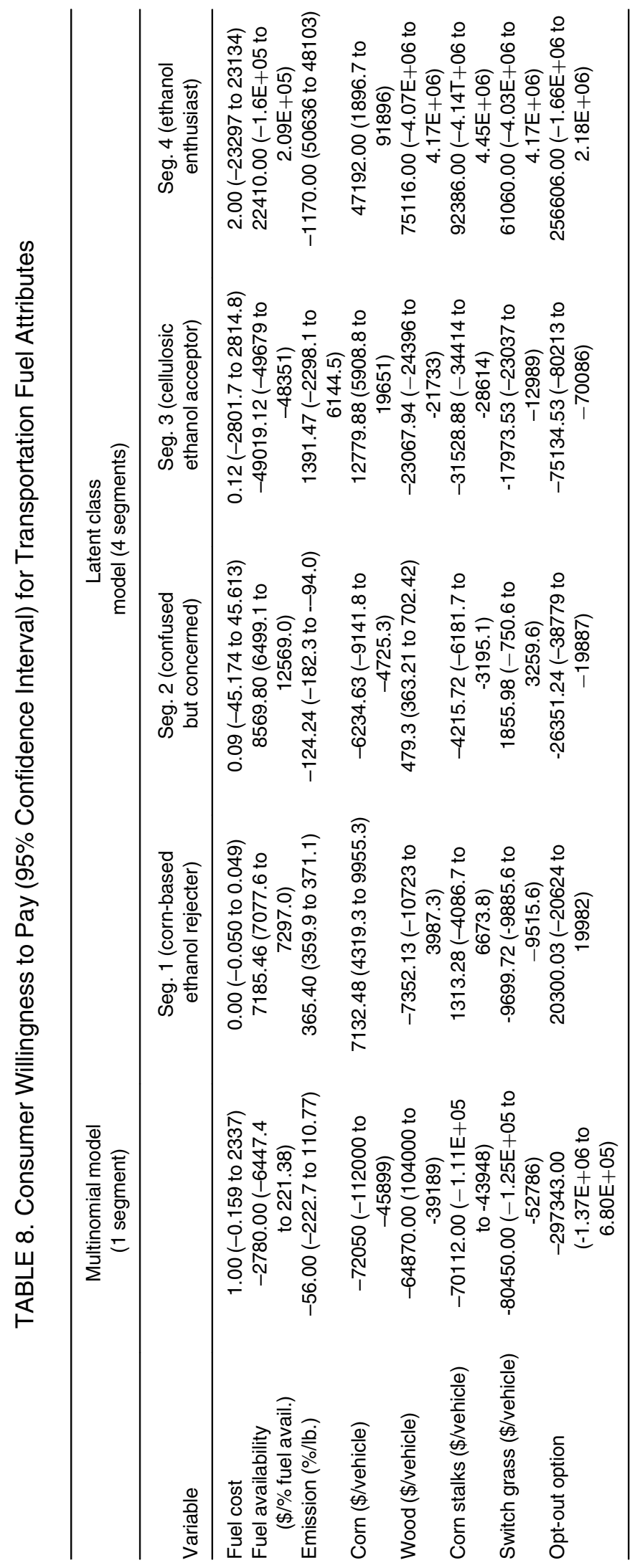


zero. Hence, members who belong to this segment are indifferent toward fuel availability.

"Corn-based ethanol rejecter" (segment 1) members are willing to pay $\$ 365.40$ (95\% CI $=$ 359.9 to 371.06 ) more in purchase and maintenance fees for a drop in every additional pound of GHG emission caused by the combustion of unit gallon of fuel. "Confused but concerned" (segment 2) members are willing to pay $\$ 124.24$ (95\% CI $=-182.3$ to -94.045$)$ less in purchase and maintenance fees for every additional pound of GHG emission caused by the combustion of unit gallon of fuel. However, "cellulosic ethanol acceptor" (segment 3) and "ethanol enthusiast" (segment 4) members are indifferent toward emission level (i.e., WTP $=$ 1391.47; $95 \% \mathrm{CI}=-3,398.1$ to $6,144.5$ and $\mathrm{WTP}=-1170 ; 95 \% \mathrm{CI}=-50,636$ to 48,103 respectively).

Results indicate that "corn-based ethanol rejecter" (segment 1) and "cellulosic ethanol acceptor" (segment 3), comprising approximately $62.95 \%$ of the population, exhibit significantly high WTP in the purchase and maintenance cost for vehicles run on corn grain ethanol compared to that of conventional gasoline and low WTP for the consumption of cellulosic ethanol compared to that of conventional gasoline. In particular, representative consumers from "corn-based ethanol rejecter" (segment 1), "cellulosic ethanol acceptor" (segment 3 ), and "ethanol enthusiast" (segment 4) are willing to pay $\$ 7,132.48$ (95\% CI $=4,319.3$ to 9,955.3); $\$ 12,779.88 \quad(95 \% \quad \mathrm{CI}=5,908.8$ to 1,9651 ); and $\$ 47,192.00$ (95\% CI $=1,896.7$ to 91,896$)$ respectively more in purchase and maintenance costs for adoption of transportation fuel derived from corn grain ethanol compared to that of conventional gasoline. "Confused but concerned" (segment 2) members are willing to pay $\$ 6,234.63$ (95\% CI = $-9,141.8$ to $-4,725.3)$ less in purchase and maintenance costs for the aforementioned fuel attribute, are willing to pay $\$ 479.30(95 \% \mathrm{CI}=$ 363.21 to 702.42 ) more in purchase and maintenance for the consumption of wood-based ethanol, and are indifferent toward the consumption of switch grass-based ethanol. "Ethanol enthusiast" (segment 4) members' WTP is not different from zero. "Cellulosic ethanol acceptor" (segment 3) and "confused but concerned" (segment 2) members are willing to pay $\$ 31,528.88(95 \% \mathrm{CI}=-34,414$ to $-28,614)$ and $\$ 4,215.72(95 \% \mathrm{CI}=-6,181.7$ to $-3,195.1)$ less respectively in purchase and maintenance costs for adoption of transportation fuel derived from corn stalks-based ethanol compared to that of conventional gasoline. However, "corn-based ethanol rejecter" (segment 1) and "ethanol enthusiast" (segment 4) members' WTP is not different from zero for the consumption of the aforementioned transportation fuel.

Members of "corn-based ethanol rejecter" (segment 1), "confused but concerned" (segment 2), and "cellulosic ethanol acceptor" (segment 3) are willing to pay $\$ 20,300.03$ (95\% $\mathrm{CI}=-20,624$ to $-19,982), \$ 26351.24(95 \%$ $\mathrm{CI}=-38,779$ to $-19,887)$, and $\$ 75,134.53$ $(95 \% \mathrm{CI}=-49,679$ to $-48,351)$ less respectively in purchase and maintenance fees for the "opt-out" option to be available. However, "ethanol enthusiast" (segment 4) members' WTP is not different from zero for the "optout" option (WTP $=\$ 256606 ; 95 \% \mathrm{CI}=$ $-1.66 \mathrm{E}+06$ to $2.18 \mathrm{E}+06)$. Consistent with MNL estimates, members of all the four segments are indifferent toward fuel cost. Note that even though mean WTP is consistently high across all segments, the WTP for all other fuel attributes vary significantly across segments.

\section{CONCLUSION}

In line with previous research, our results shed light on interesting consumer demand factors (Horbach 2008; Kesidou and Demirel 2012). Our findings show that consumers fall under one of the four types of segments: cornbased ethanol rejecter, confused but concerned, cellulosic ethanol accepter, and ethanol enthusiast, based on their attitude toward consumption of alternative fuels. The results based on sociodemographic features show that age of consumers and state of residency play an important role in determining their propensity for alternative fuel consumption. In particular, we find younger consumers are less likely to 
use flexible fuels compared to middle-aged consumers, who are more likely to accept flexible fuels as an alternative to conventional gasoline.

Our research demonstrates that when product-offering decisions by manufacturing firms are driven by administrative innovations rather than technological innovations, it creates market distortions. In particular, even though these products are characterized as eco-friendly, they may not optimize consumer utility and hence may fail to generate adequate consumer enthusiasm. Specifically, in this study, we show that lack of consumer interest is reflected by consumers' low willingness to pay. This also confirms that successful new product diffusion requires product supply to meet adequate demand.

In terms of consumers' willingness to pay for flexible fuel, the results show that consumers are not willing to pay more to switch from conventional gasoline to the alternative transportation fuels. Furthermore, examination of consumer preference heterogeneity shows that fuel availability is an important factor that determines fuel choice. We find that this is particularly true in the case of customers who fall under the "corn-based ethanol rejecters" and "confused but concerned" segments. Consumers under these two segments are environmentally more conscious and hence willing to pay more for flexible fuels (i.e., E-10 and E-85), provided these fuel stations are conveniently located. Although the two consumer segments in our sample show preference for flexible fuels, this preference seems to be contingent on their freedom to switch back to conventional gasoline. Findings suggests that it's best for firms to launch a sustainable fuel in the market after it has been fully tested and/or endorsed by a reputable source for consumers to feel that it is safe to use.

Overall, this study makes three unique contributions to the literature, which have implications for both researchers and policy makers. First, our study contributes to the slow-growing field, or rather sidelined field, of sustainable product research. In particular, we are among the first few studies examining consumer preference and price sensitivity toward flexible fuel consumption in the United States. Most research to date on flexible fuels has been conducted in European markets (See Arundel and Kemp 2009; Kemp 2009). Additionally, prior research shows that one of the main drivers for firms to pursue eco-innovations is their desire to meet customer demands (Horbach 2008; Kesidou and Demirel 2012). Our study digs deeper to explore the factors that aid in understanding and fulfilling customer demands and expectations in a profitable manner.

Second, our rigorous econometric approach contributes to the limited empirical analyses for eco-innovation drivers (Horbach 2008). Our results not only show consumer preferences for flexible fuel types, but they also show their price-sensitivity levels. This is an important contribution to the eco-innovation literature because it allows both firms and policy makers to get a better sense of the type of fuel that consumers are likely to adopt and at what price levels. Furthermore, firms undertake innovation only if it makes sense to the innovating firm that it will be able to capture the demand effectively and be able to make products. Understanding of customer demands and their price sensitivity will allow firms to effectively allocate their resources as well as recoup their investments faster.

Third, our study is a step toward the effort of bringing the topic of environmentally safe products to the forefront so much can be explored and learned about building sustainable products in the world and North America in particular. Research in this area will not only benefit the environment, firms, and consumers but also inform environmental policies. Furthermore, understanding consumer need for flexible fuel will help policy makers not only to draft policies that are perceived as less biased but also an effective investment of taxpayers' money, so that the outcomes are favorable and reduce the pinch of double taxation. We strongly believe that research in the field of eco-innovations will allow the formation of environmental theories that focus on a better understanding of how pull and push factors 
influence sustainable product production and diffusion.

\section{Policy Prescriptions}

The results of this study provide two specific factors to consider for future policies. First, the results show the different types of consumer segments and their level of price sensitivity toward alternative fuel choices, which should help guide future policies that are focused on drafting guidelines for overcoming consumer price sensitivity. Second, based on the sociodemographic findings of this study, future policies should focus on providing incentives for younger generations to increase their willingness to use alternative fuels. This is an important result for the future of alternative fuels because the sooner the younger generation starts using alternative fuels, the longer and better the prospects are for the industry and the environment.

\section{Limitations and Future Research}

Like most research studies, our study has limitations that are important to note. First, our study only focuses on understanding consumer preferences for flexible fuels and not flexiblefuel vehicles. This somewhat limits the generalizability of the results because vehicle choice plays a critical role in the comprehensive understanding of consumer preferences for flexible fuels. We hope that future research will focus on understanding consumer preferences for flexible-fuel vehicles and how this choice set influences the flexible-fuel choice. Second, our results show that consumers are indifferent toward fuel cost, which suggests that other factors play a role in forming consumer preferences. Unfortunately, our study can only speculate on these factors without much confidence. Future research can focus on examining what other factors or combination of factors exert maximum influence on consumer decisions. Third, our study does not capture any aspect of culture. We suggest future research to focus on examining cultural differences because these differences may help us better understand consumer preferences for eco- innovations. Additionally, cultural understanding will also help firms with future expansion overseas. Last, our study does not capture consumers' perceptions of existing flexible-fuel policies and government's investment in sustainable-fuel projects. This understanding is critical for both firms and policy makers to effectively position and cater to the needs of the customers. It is our hope that our study will serve as a catalyst for future research in the United States that will take the findings of this study a step further. We also hope our study will allow others to understand implications associated with consumer decision making that can be leveraged to generate better sustainable fuels along with policies that effectively help in achieving these goals with fewer biases.

\section{REFERENCES}

Ahn, J., G. Jeong, and Y. Kim. 2008. A forecast of household ownership and use of alternative fuel vehicles: A multiple discrete-continuous choice approach. Energy Economics 30:2091-2104. http://dx.doi.org/10.1016/j. eneco.2007.10.003

Alfnes, F. 2004. Stated preferences for imported and hormone-treated beef: Application of a mixed logit model. European Review of Agricultural Economics 31:19-37. http://dx.doi.org/10.1093/erae/31.1.19

Allenby, G. M. 1990. Hypothesis testing with scanner data: The advantage of Bayesian methods. Journal of Marketing Research 27:379-389. http://dx.doi.org/ 10.2307/3172624

Amendah, E., and J. Park. 2008. Consumer involvement and psychological antecedents on eco-friendly destinations: Willingness to pay more. Journal of Hospitality \& Leisure Marketing 17 (3-4): 262-283. http://dx.doi. org/10.1080/10507050801984859

Arundel, A., and R. Kemp. 2009. Measuring eco-innovation. UNU-MERIT Working Paper Series-017.

Audretsch, D. B., and M. P. Feldman. 1996. R\&D spillovers and the geography of innovation and production. The American Economic Review 630-640.

Bagozzi, R. P., and Y. Yi. 1990. Assessing method variance in multitrait-multimethod matrices: The case of self-reported affect and perceptions at work. Journal of Applied Psychology 75 (5): 547-560. http://dx.doi. org/10.1037/0021-9010.75.5.547

Bagozzi, R. P., and Y. Yi. 1991. Multitrait-multimethod matrices in consumer research. Journal of Consumer Research 17 (4): 426-439. http://dx.doi.org/10.1086/ 208568

Beard, J. G., and M. G. Ragheb. 1983. Measuring leisure motivation. Journal of Leisure Research 15:219-228. 
Bech, M., and D. Gyrd-Hansen. 2005. Effects coding in discrete choice experiments. Health Economics 14 (10):1079-1083. http://dx.doi.org/10.1002/hec.984

Bhattacharjee, S., D. Petrolia, and C. Herndon. 2008. Estimating willingness to pay for E10 fuel: A contingent valuation method. Paper presented at the annual meeting of the Southern Agricultural Economics Association, Dallas, Texas.

Boxall, P. C., and W. L. Adamowicz. 2002. Understanding heterogeneous preferences in random utility models: A latent class approach. Environmental and Resource Economics 23:421-446. http://dx.doi.org/ 10.1023/A:1021351721619

Boxall, P. C., and B. Macnab. 2000. Exploring the preferences of wildlife recreationists for features of boreal forest management: A choice experiment approach. Canadian Journal of Forest Research 30 (12): 1931-1941. http://dx.doi.org/10.1139/x00-128

Bunch, D. S., M. Bradley, T. F. Golob, R. Kitamura, and G. P. Occhiuzzo. 1993. Demand for clean-fuel vehicles in California: A discrete-choice stated preference pilot project. Transportation Research Part A: Policy and Practice 27 (3): 237-253. http://dx.doi.org/ 10.1016/0191-2615(93)90033-7

Burke, A. 2004. Present status and marketing prospects of the emerging hybrid-electric and diesel technologies to reduce $\mathrm{CO}_{2}$ emissions of new light-duty vehicles in California. Report UCD-ITS-RR-04-02. Davis, CA: University of California.

Carrillo-Hermosilla, J., P. del Río, and T Könnölä. 2010. Diversity of eco-innovations: Reflections from selected case studies. Journal of Cleaner Production 18:10731083. http://dx.doi.org/10.1016/j.jclepro.2010.02.014

Chaudhuri, M., G. T. Tonsor, and H. C. Peterson. 2011. Factor demand analysis for ethanol in the U.S. refinery industry. B. E. Journal of Economic Analysis and Policy 11(1): 21.

Conway, S., and F. Steward. 1998. Networks and interfaces in environmental innovation: A comparative study in the UK and Germany. Journal of High Technology Management Research 2:239-254. http://dx.doi.org/ 10.1016/S1047-8310(98)90006-2

Cummings, R. G., G. W. Harrison, and E. E. Rutström. 1995. Homegrown values and hypothetical surveys: Is the dichotomous choice approach incentive-compatible? The American Economic Review 85:260-266.

Ewing, G., and E. Sarigollu. 2000. Assessing consumer preferences for clean-fuel vehicles: A discrete choice experiment. Journal of Public Policy \& Marketing 19:106-118. http://dx.doi.org/10.1509/jppm.19.1.106. 16946

Eysenbach, G., and J. Wyatt. 2002. Using the Internet for surveys and health research. Journal of Medical Internet Research 4 (2): e13.

Foster, C., and K. Green. 2002. Environmental innovation in industry: The importance of environmentally-driven users. International Journal of Environmental Technology and Management 2:303-314. http://dx.doi.org/ 10.1504/IJETM.2002.000793

Gao, Z., and T. C. Schroeder. 2009. Effects of label information on consumer willingness-to-pay for food attributes. American Journal of Agricultural Economics 91 (3): 795-809. http://dx.doi.org/10.1111/j.14678276.2009.01259.x

Gerard, D., and L. B. Lave. 2005. Implementing technology-forcing policies: The 1970 Clean Air Act Amendments and the introduction of advanced automotive emissions controls in the United States. Technological Forecasting and Social Change 72:761-778. http://dx. doi.org/10.1016/j.techfore.2004.08.003

Gray-Lee, J. W., D. L. Scammon, and R. N. Mayer. 1994. Review of legal standards for environmental marketing claims. Journal of Public Policy Marketing 13:155-164.

Greene, D. L. 1989. Motor fuel choice: An econometric analysis. Transportation Research 23:243-253. http:// dx.doi.org/10.1016/0191-2607(89)90006-X

Greene, W. H., and D. A. Hensher. 2003. A latent class model for discrete choice analysis: Contrasts with mixed logit. Transportation Research Part B: Methodological 37:681-698. http://dx.doi.org/10.1016/ S0191-2615(02)00046-2

Grunert, K. G. 2005. Food quality and safety: Consumer perception and demand. European Review of Agricultural Economics 32 (3): 369-391. http://dx.doi.org/ 10.1093/eurrag/jbi011

Hanemann, W. M. 1982. Applied welfare analysis with qualitative response models. American Journal of Agricultural Economics 66:332-341. http://dx.doi.org/ $10.2307 / 1240800$

Heiskanen, E., K. Hyvönen, M. Niva, M. Pantzar, P. Timonen, and J. Varjonen (2007). User involvement in radical innovation: Are consumers conservative? European Journal of Innovation Management 10 (4): 489-509. http://dx.doi.org/10.1108/14601060710828790

Hellström, T. 2007. Dimensions of environmentally sustainable innovation: The structure of eco-innovation concepts. Sustainable Development 15 (3): 148-159. http://dx.doi.org/10.1002/sd.309

Horbach, J. 2008. Determinants of environmental innovation-New evidence from German panel data sources. Research Policy 37 (1): 163-173. http://dx.doi.org/ 10.1016/j.respol.2007.08.006

Horne, M., M. Jaccard, and K. Tiedemann. 2005. Improving behavioral realism in hybrid energy-economy models using discrete choice studies of personal transportation decisions. Energy Economics 27 (1): 59-77. http://dx.doi.org/10.1016/j.eneco.2004.11.003

Huang, C. L. 1996. Consumer preferences and attitudes towards organically grown produce. European Review of Agricultural Economics 23 (3): 331-342. http://dx. doi.org/10.1093/erae/23.3.331 
Jansson, J. 2011. Consumer eco-innovation adoption: Assessing attitudinal factors and perceived product characteristics. Business Strategy and the Environment 20 (3): 192-210. http://dx.doi.org/10.1002/ bse. 690

Kemp, R. 2009. From end-of-pipe to system innovation. Paper presented at the DRUID Summer Conference, Copenhagen, pp. 17-19.

Kesidou, E., and P. Demirel. 2012. On the drivers of ecoinnovations: Empirical evidence from the UK. Research Policy 41 (5): 862-870. http://dx.doi.org/ 10.1016/j.respol.2012.01.005

Krinsky, I., and A. L. Robb. 1986. On approximating the statistical properties of elasticities. The Review of Economics and Statistics 68 (4): 715-719. http://dx.doi. org/10.2307/1924536

Kuhfeld, W. F. 2005. Marketing research methods in SAS: Experimental design, choice, conjoint, and graphical techniques. Cary, NC: SAS Institute.

Lanjouw, J. O., and A. Mody 1996. Innovation and the international diffusion of environmentally responsive technology. Research Policy 25 (4): 549-571. http:// dx.doi.org/10.1016/0048-7333(95)00853-5

Li, X., C. D. Clark, K. L. Jensen, S. T. Yen, and B. C. English. 2013. Consumer purchase intentions for flexible-fuel and hybrid-electric vehicles. Transportation Research Part D: Transport and Environment 18: 9-15. http://dx.doi.org/10.1016/j.trd.2012.08.001

Loureiro, M. L., and W. J. Umberger. 2007. A choice experiment model for beef: What US consumer responses tell us about relative preferences for food safety, country-of-origin labeling and traceability. Food Policy 32 (4): 496-514. http://dx.doi.org/ 10.1016/j.foodpol.2006.11.006

Louviere, J. J., and T. Islam. 2008. A comparison of importance weights and willingness-to-pay measures derived from choice-based conjoint, constant sum scales and best-worst scaling. Journal of Business Research 61 (9): 903-911. http://dx.doi.org/10.1016/j. jbusres.2006.11.010

Lusk, J. L., J. A. Fox, T. C. Schroeder, J. Mintert, and M. Koohmaraie. 2001. In-store valuation of steak tenderness. American Journal of Agricultural Economics 83 (3): 539-550. http://dx.doi.org/10.1111/0002-9092.00176

Lusk, J. L., J. Roosen, and J. A. Fox. 2003. Demand for beef from cattle administered growth hormones or fed genetically modified corn: A comparison of consumers in France, Germany, the United Kingdom, and the United States. American Journal of Agricultural Economics 85 (1): 16-29. http://dx.doi.org/10.1111/14678276.00100

Lusk, J. L., and F. B. Norwood. 2005. Effect of experimental design on choice-based conjoint valuation estimates. American Journal of Agricultural Economics 87 (3): 771-785. http://dx.doi.org/10.1111/j.14678276.2005.00761.x
Mahajan, V., S. Sharma, and R. A. Bettis. 1988. The adoption of the M-form organizational structure: A test of imitation hypothesis. Management Science 34 (10): 1188-1201. http://dx.doi.org/10.1287/mnsc.34. 10.1188

McFadden, D. 1974. Conditional logit analysis of qualitative choice behavior. In Frontiers in econometrics, ed. P. Zarembka, 105-142. New York: Academic Press.

McFadden, D. 1986. The choice theory approach to market research. Marketing Science 5 (4): 275-297. http:// dx.doi.org/10.1287/mksc.5.4.275

Melnikov, O. 2000. Demand for differentiated durable products: The case of the US computer printer market. Manuscript, Department of Economics, Yale University.

Menon, A., and A. Menon. 1997. Enviropreneurial marketing strategy: The emergence of corporate environmentalism as market strategy. Journal of Marketing 61 (1). http://dx.doi.org/10.2307/1252189

Moller, R. M. (2005). Brief on biomass and cellulosic ethanol. California Research Bureau. http://large.stanford. edu/courses/2010/ph240/sangha1/docs/05-010.pdf

Muthén, L. K., and B. O. Muthén 2001. Statistical analysis with latent variables. Los Angeles: Muthén \& Muthén. Muthén Statistical Analysis with Latent Variables2001.

Ottman, J. A. 1998. Green marketing: Opportunity for innovation. Chicago: NTC Business Books.

Ozaki, R. 2011. Adopting sustainable innovation: What makes consumers sign up to green electricity? Business Strategy and the Environment 20 (1): 1-17. http:// dx.doi.org/10.1002/bse.650

Peattie, K. 2001. Golden goose or wild goose? The hunt for the green consumer. Business Strategy and the Environment 10 (4): 187-199. http://dx.doi.org/ $10.1002 / \mathrm{bse} .292$

Peattie, K., and A. Crane. 2005. Green marketing: Legend, myth, farce or prophesy? Qualitative Market Research: An International Journal 8 (4): 357-370.

Porter, M. E., and C. Van der Linde. 1995. Green and competitive: Ending the stalemate. Harvard Business Review 73 (5): 120-134.

Potoglou, D., and P. S. Kanaroglou. 2007. Household demand and willingness to pay for clean vehicles. Transportation Research Part D: Transport and Environment 12 (4): 264-274. http://dx.doi.org/10.1016/j. trd.2007.03.001

Pujari, D. 2006. Eco-innovation and new product development: Understanding the influences on market performance. Technovation 26 (1): 76-85. http://dx.doi.org/ 10.1016/j.technovation.2004.07.006

Pujari, D., K. Peattie, and G. Wright. 2004. Organizational antecedents of environmental responsiveness in industrial new product development. Industrial Marketing Management 33 (5): 381-391. http://dx.doi.org/ $\underline{10.1016 / \text { j.indmarman.2003.09.001 }}$ 
Pujari, D., G. Wright, and K. Peattie 2003. Green and competitive: Influences on environmental new product development performance. Journal of Business Research 56 (8): 657-671. http://dx.doi.org/10.1016/ S0148-2963(01)00310-1

Rennings, K. 2000. Redefining innovation-Eco-innovation research and the contribution from ecological economics. Ecological Economics 32:319-332. http://dx. doi.org/10.1016/S0921-8009(99)00112-3

Rowlands, I. H., D. Scott, and P. Parker. 2003. Consumers and green electricity: Profiling potential purchasers. Business Strategy and the Environment 12 (1): 36-48. http://dx.doi.org/10.1002/bse.346

Savage, S. J., and D. M. Waldman. 2008. Learning and fatigue during choice experiments: A comparison of online and mail survey modes. Journal of Applied Econometrics 23 (3): 351-371. http://dx.doi.org/ 10.1002/jae.984

Shrum, L. J., J. A. McCarty, and T. M. Lowrey. 1995. Buyer characteristics of the green consumer and their implications for advertising strategy. Journal of Advertising 24 (2): 71-82. http://dx.doi.org/10.1080/ 00913367.1995 .10673477

Small, K. A., and H. S. Rosen. 1981. Applied welfare economics with discrete choice models. Econometrica 49:43-46. http://dx.doi.org/10.2307/1911129

Summers, J. C., J. F. Skowron, and M. J. Miller. 1993. Use of light-off catalysts to meet the California LEV/ ULEV standards (No. 930386). SAE Technical Paper. http://dx.doi.org/10.4271/930386

Swait, J. 1994. A structural equation model of latent segmentation and product choice for cross-sectional revealed preference choice data. Journal of Retailing and Consumer Services 1:77-89. http://dx.doi.org/ 10.1016/0969-6989(94)90002-7

Swait, J., and W. Adamowicz. 2001. The influence of task complexity on consumer choice: A latent class model of decision strategy switching. Journal of Consumer Research 28 (1): 135-148. http://dx.doi.org/10.1086/ 321952

Teece, D. J. 1980. The diffusion of an administrative innovation. Management Science 26 (5): 464-470. http://dx.doi.org/10.1287/mnsc.26.5.464

Tully, S. M., and R. S. Winer. 2013. Are people willing to pay more for socially responsible products: A metaanalysis. http://ssrn.com/abstract_=_2240535.

Veisten, K. 2007. Willingness to pay for eco-labelled wood furniture: Choice-based conjoint analysis versus open-ended contingent valuation. Journal of Forest Economics 13 (1): 29-48. http://dx.doi.org/10.1016/j. jfe.2006.10.002

Vermunt, J. K. 2007. Multilevel mixture item response theory models: An application in education testing. Proceedings of the 56th Session of the International Statistical Institute, Lisbon, Portugal.

Vermunt, J. K., and J. Magidson. 2008. LG-syntax user's guide: Manual for Latent GOLD 4.5 syntax module.

Wald, A. 1943. Tests of statistical hypotheses concerning several parameters when the number of observations is large. Transactions of the American Mathematical Society 54 (3): 426-482. http://dx.doi.org/10.1090/ S0002-9947-1943-0012401-3

Wong, V., W. Turner, and P. Stoneman. 1996. Marketing strategies and market prospects for environmentallyfriendly consumer products. British Academy of Management 7 (3): 263-281.

Wyatt, J. C. 2000. When to use web-based surveys. Journal of the American Medical Informatics Association 7 (4): 426-430. http://dx.doi.org/10.1136/jamia.2000.0070426

Zhang, T., S. Gensler, and R. García. 2011. A study of the diffusion of alternative fuel vehicles: An agent-based modeling approach. Journal of Product Innovation Management 28 (2): 152-168. http://dx.doi.org/ 10.1111/j.1540-5885.2011.00789.x 


\section{APPENDIX A: Confirmatory Factor Analysis}

\section{Confirmatory Factor Analysis}

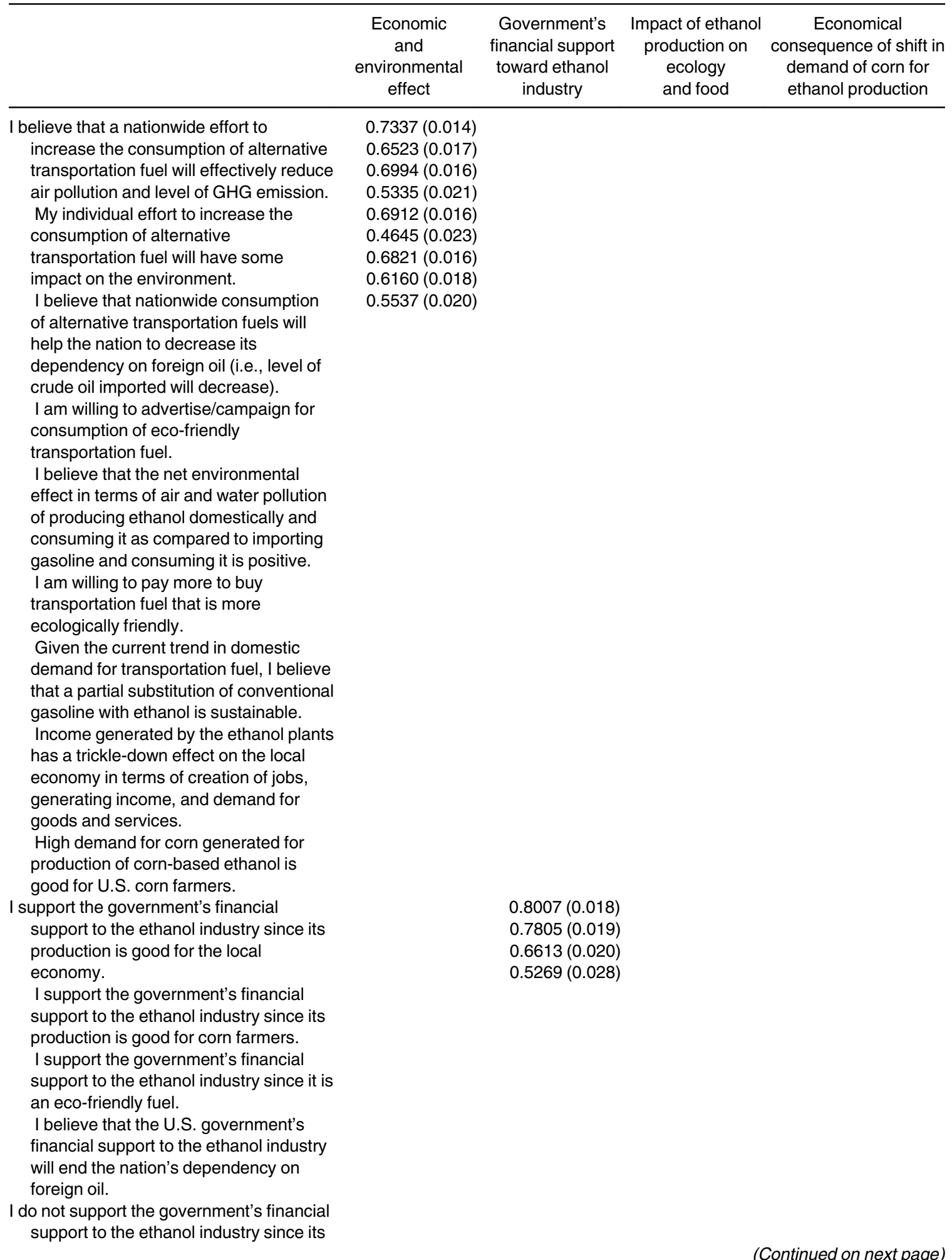




\section{Confirmatory Factor Analysis (Continued)}

\begin{tabular}{|c|c|c|c|c|}
\hline & $\begin{array}{c}\text { Economic } \\
\text { and } \\
\text { environmental } \\
\text { effect }\end{array}$ & $\begin{array}{l}\text { Government's } \\
\text { financial support } \\
\text { toward ethanol } \\
\text { industry }\end{array}$ & $\begin{array}{l}\text { Impact of ethanol } \\
\text { production on } \\
\text { ecology } \\
\text { and food }\end{array}$ & $\begin{array}{l}\text { Economical } \\
\text { consequence of shift in } \\
\text { demand of corn for } \\
\text { ethanol production }\end{array}$ \\
\hline production leads to deforestation and & & & $0.7153(0.019)$ & \\
\hline loss of grasslands. & & & $0.5988(0.022)$ & \\
\hline I do not support the government's & & & $0.7465(0.018)$ & \\
\hline financial support to the ethanol industry & & & & \\
\hline since its production leads to climate & & & & \\
\hline change and increased level of GHG & & & & \\
\hline emission. & & & & \\
\hline I do not support the government's & & & & \\
\hline financial support to the ethanol industry & & & & \\
\hline since its production induces food price & & & & \\
\hline volatility. & & & & \\
\hline High demand in corn for production of & & & & $0.8460(0.018)$ \\
\hline corn-based ethanol is adversely & & & & $0.8040(0.018)$ \\
\hline affecting overall food prices. & & & & $0.5813(0.024)$ \\
\hline High demand in corn for production of & & & & \\
\hline corn-based ethanol is adversely & & & & \\
\hline affecting production of corn for human & & & & \\
\hline food consumption. & & & & \\
\hline High demand in corn for production of & & & & \\
\hline corn-based ethanol is providing non- & & & & \\
\hline $\begin{array}{l}\text { corn-producing farmers incentives to } \\
\text { switch production and grow more corn. }\end{array}$ & & & & \\
\hline
\end{tabular}

Appendix B: Fit Summary

\section{Fit Summary}

Goodness of Fit Index (GFI)

0.9224

Standardized RMSR (SRMSR)

0.0451

RMSEA estimate

0.0658

Bentler Comparative Fit Index

0.9311

Bentler-Bonett NFI

0.9209 